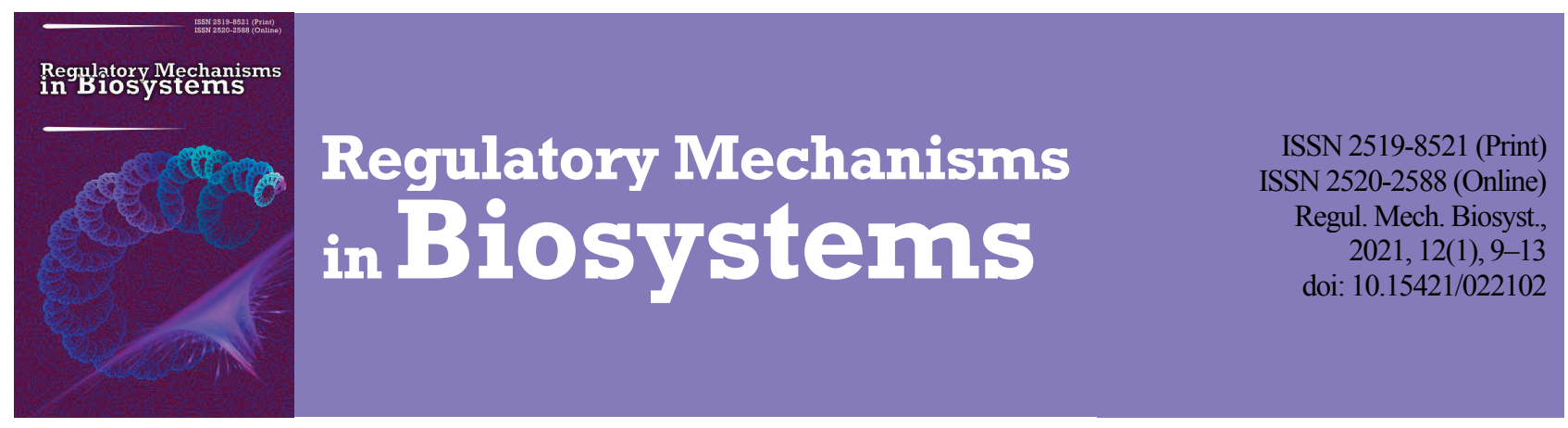

\title{
Enrichment of chicken table eggs with lycopene and astaxanthin
}

\author{
L. V. Shevchenko, V. A. Davydovych, S. V. Midyk, O. O. Bezusa \\ National University of Life and Environmental Sciences of Ukraine, Kyiv, Ukraine
}

Article info

Received 02.02.2021

Received in revised form 05.03 .2021

Accepted 06.03.2021

National University

of Life and Environment

Sciences of Ukraine,

Heroïv Oborony st., 15 ,

Kyiv, 03041, Ukraine.

Tel.: +38-050-193-10-29.

E-mail:

shevchenko_laris@ukr.net

\begin{abstract}
Shevchenko, L. V., Davydovych, V. A., Midyk, S. V., \& Bezusa, O. O. (2021). Enrichment of chicken table eggs with lycopene and astaxanthin. Regulatory Mechanisms in Biosystems, 12(1), 9-13. doi:10.15421/022102
\end{abstract}

Ensuring an attractive commercial appearance of egg yolks involves the introduction to the feed of laying hens of the dyes of various origins. Recently, egg producers have preferred natural dyes, which include carotenoids: lycopene and astaxanthin, which can be deposited in chicken egg yolks. The aim of this study was to determine the quality of egg yolks, colour intensity and carotenoid composition of yolks when oil extracts of lycopene (20, 40 and $60 \mathrm{mg} / \mathrm{kg}$ feed) or astaxanthin $(10,20$ and $30 \mathrm{mg} / \mathrm{kg}$ feed) are included in the chickens' diet. 45 High Line W36 chickens at the age of 24 weeks were used for the experiment. Feeding laying hens with supplements of lycopene oil extracts at doses of 30,40 and $60 \mathrm{mg} / \mathrm{kg}$ and astaxanthin at doses of 10,20 and $30 \mathrm{mg} / \mathrm{kg}$ of feed for 30 days in increasing concentrations did not affect egg weight, albumen height, Haugh unit, strength and the thickness of the shell. The addition of lycopene to the diet of chickens at doses of $20 \mathrm{mg} / \mathrm{kg}$ of feed increased the content of lycopene, unidentified carotenoids and the total content of carotenoids in the yolks, but did not change the intensity of their colour. Increasing the dose of lycopene in the diet of chickens to 40 and $60 \mathrm{mg} / \mathrm{kg}$ of feed increased the content of lycopene in yolks and the intensity of their colour to 7.4 and 8.0 points against 5.6-6.1 points in the control, but did not affect the content of $\beta$-carotene and total carotenoids in the yolks. The addition of astaxanthin oil extract at doses of $10,20 \mathrm{and} 30 \mathrm{mg} / \mathrm{kg}$ of feed increased the content of astaxanthin, $\beta$-carotene and total carotenoids in chicken egg yolks and increased the intensity of their colour to $12.8,14.8$ and 14.4 points on a 16-point colour scale YolkFanTM. To obtain chicken table eggs with a given colour of the yolks, it is advisable to use the addition of astaxanthin oil extract in doses from 10 to $20 \mathrm{mg} / \mathrm{kg}$ of feed for 30 days. The results of the research can be used to develop a technology for the production of functional table eggs enriched with carotenoids of natural origin with an attractive colour for consumers.

Keywords: yolk colour; carotenoids; quality of eggs; colour scale.

\section{Introduction}

The colour of the egg yolk is an important factor that determines its attractiveness to the consumer (Honda et al., 2020). It is known that yolks are coloured by carotenoids, which are not able to be synthesized in the body of chickens and must come with feed (Nimalaratne \& Wu, 2015; Nabi et al., 2020). In recent years, most food egg producers have abandoned synthetic dyes and preferred natural ones, including those of plant origin: products of processing tomatoes as a source of lycopene and various microscopic algae as a source of astaxanthin (Magnuson et al., 2018), and added vitamins to the diet supplements (Danchuk et al., 2019). Astaxanthin effectively pigments the yolk (Heng et al., 2020) and exhibits strong antioxidant activity, which is 10 times higher than $\beta$-carotene and 550 times higher than vitamin $\mathrm{E}$. The intake of astaxanthin with food, including eggs, in the body of consumers, reduces the risk of cardiovascular disease, some cancers and eye diseases (Fakhri et al., 2018), increases the activity of antioxidant enzymes (Dose et al., 2016; Li et al., 2018) and enhances the body's immune response (Farruggia et al., 2018). Lycopene is found in significant concentrations in tomatoes and processed products and is one of 20 carotenoids found in human blood and tissues (Boyacioglu et al., 2016). Several in vivo and in vitro studies have shown that lycopene is a potent antioxidant (Bacanli et al., 2017) that is able to absorb free radicals, inhibit signaling pathways and activate antioxidant enzymes such as superoxide dismutase, glutathione peroxidase and catalase. Enrichment of edible eggs with lycopene or astaxanthin allows one not only to obtain an attractive colour of egg yolks, but also to improve their antioxidant composition and functional properties. However, studies of the effectiveness of different sources of lycopene and astaxanthin in laying hens contain differences in the optimal dose of carotenoids depending on the basic diet, combination with different oils, composition and form of supple- ments (dry powder, paste, oil extract) in the diet. Therefore, the aim of our study was to determine the effect of different doses of natural oil extracts of lycopene and astaxanthin on the quality of eggs and carotenoid composition and colour of yolks.

\section{Materials and methods}

All experiments were performed in compliance with the requirements of the European Convention for the Protection of Vertebrate Animals Used for Scientific Experiments or Other Scientific Purposes of 1986, as well as the Law of Ukraine "On Protection of Animals from Cruelty" of 21.02.2006, 3447-IV.

The study was conducted on the basis of the Faculty of Veterinary Medicine of the National University of Life and Environmental Sciences of Ukraine. For this purpose, 45 laying hens of the High-line W36 crosscountry aged 23 weeks were used, which were divided into three groups according to the principle of analogous groups: 15 heads in each. Chickens were kept in cage batteries for 5 heads each for 90 days (Table 1). Laying hens were fed lycopene supplements in the form of $6 \%$ oil extract obtained from tomatoes (LycoRed, Israel), as well as astaxanthin supplements $-10 \%$ oil extract obtained from the biomass of algae Haematococcus pluvialis (ALGAE Technologies, Israel). Throughout the experiment, chickens were fed complete feed, which consisted of the following components $(\mathrm{g} / \mathrm{kg})$ : corn -500.85 , wheat -90.00 , soybean meal -179.00 , sunflower meal -96.00 , limestone -114.00 , monocalcium phosphate 10.00 , table salt, intox (sorbent) -1.00 , methionine -1.30 , Proactive (probiotic) -1.00 , mineral complex Rovimix -1.00 , lysine -1.60 , Millerzeim III 150 (multienzyme additive) -0.15 , sodium sulfate -1.30 , choline chloride -0.30 , vitamin complex $-0.20 .100 \mathrm{~g}$ of compound feed contains: moisture $-10.40 \mathrm{~g}$, crude protein $-16.22 \mathrm{~g}$, calcium $-4.76 \mathrm{~g}$, total 
phosphorus $-0.77 \mathrm{~g}$, sodium $-0.20 \mathrm{~g}$, metabolic energy $-291.2 \mathrm{kcal}$. From 1 to 30 days of the experiment, laying hens were fed an average $91 \mathrm{~g}$, and from 31 to 90 days $-97 \mathrm{~g}$ of feed per head per day. Experimental diets were prepared for 4 days, the feed mixture was mixed and stored in airtight food plastic containers. Watering of chickens was carried out at will with the use of cup drinkers. Daylight was 16 hours (illumination 30 lux), darkness -8 hours. The indoor air temperature was maintained at $21-23^{\circ} \mathrm{C}$, and the relative humidity was $60-62 \%$.

Table 1

Scheme of the experiment

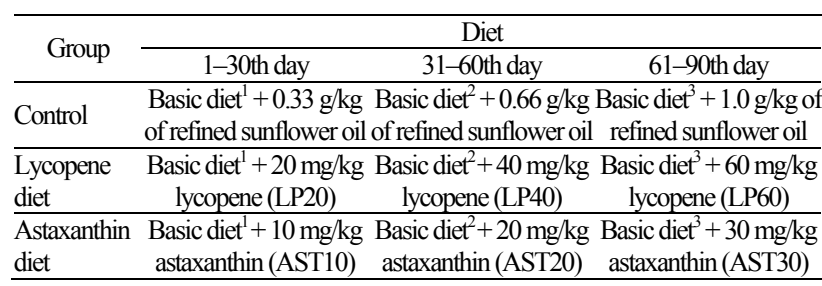

Note: basic diet, the same superscripts 1,2, 3 show the same content of refined sunflower oil in the diet.

For the research, 5 eggs were selected from each group of chickens on the 30-31st, 60-61st and 90-91st days of the experiment. Determination of egg weight, albumen height, yolk colour (16-point YolkFanTM colour scale), Haugh unit, shell strength, and shell thickness was performed using a DET 6000 digital egg tester (NABEL Co., Ltd., Japan). The content of carotenoids in chicken egg yolks was determined by high performance liquid chromatography (HPLC). The research was performed in Research on Demand LAB, Zaporizhia (accreditation certificate No. GAS.L 804.017). Before the study of egg yolk samples by HPLC, alkaline hydrolysis and extraction of carotenoids were performed (GOST EN 12823-2-2014 Produkty pishhevye. Opredelenie soderzhaniya vitamina A metodom vysokoeffektivnoj zhidkostnoj khromatografii. Chast 2. Izmerenie soderzhaniya beta-karotina (Pereizdanie) [GOST EN 12823-2-2014 Foodstuffs. Determination of vitamin A by high performance liquid chromatography. Part 2. Measurement of $\beta$-carotene]).

After partial evaporation of the hexane extracts in a water bath under a stream of nitrogen they were dried under vacuum to a dry residue in a vacuum desiccator. The unsaponified residue was dissolved in $2 \mathrm{~mL}$ of mobile phase hexane: acetone in a volume ratio of 90:10 and filtered using a syringe with a PTFE filter $0.22 \mu \mathrm{m}, 13 \mathrm{~mm}$ Luer Syringe Filter. The obtained solutions of egg yolk extracts and standard solutions were used for chromatographic analysis on a HPLC system consisting of a Shimadzu LC-10 AD pump, a Kariba Instruments Model RC 3099 sampling device and a Shimadzu SPD-10 A spectrophotometric detector (Shimadzu, Japan). Waves of $480 \mathrm{~nm}$. Stationary phase: Phenomenex P/NO 00F0227E0, Type Lichrosorb 5 SIL 60A, Size 150 x $4.60 \mathrm{~mm} 5 \mu \mathrm{m}, \mathrm{S} / \mathrm{NO}$ 192315; mobile phase: hexane: acetone (90:10), which contained $0.1 \%$ BHT (butylhydroxytoluene); flow rate $-1.2 \mathrm{~cm}^{3} / \mathrm{min}$, the volume of the injected sample $-20 \mathrm{~mm}^{3}$. Measurements of the optical density of the standards were performed on a spectrophotometer Beckman DU 530 (Beckman Coulter, Inc., USA) at a wavelength of $400-800 \mathrm{~nm}$ in a cuvette made of optical glass with an optical path length of $1 \mathrm{~cm}$. As a solution (solvent) acetone was used. Identification of carotenoids was performed by comparing the retention time of individual peaks on the chromatograms of the sample solution and standard solutions. In the study of egg yolk samples for lycopene and $\beta$-carotene content, an optimized mobile phase was used - acetonitrile: (methanol $+0.05 \mathrm{~mol} / \mathrm{L}$ ammonium acetate): dichloromethane in a volume ratio of $75: 20: 5$, containing $0.1 \%$ BHT and $0.05 \%$ TEA (triethylamine). Stationary phase: Jupiter $5 \mathrm{u} \mathrm{C18} \mathrm{300A.}$ Flow rate: $1.5 \mathrm{~cm}^{3} / \mathrm{min}$; volume of the entered sample: $50 \mathrm{~mm}^{3}$; wavelength $480 \mathrm{~nm}$. Absolute calibration was used to quantify the content of astaxanthin, lycopene and $\beta$-carotene in egg yolks.

Statistical processing of the obtained results was performed using the ANOVA, the data in the tables are presented in the form of $\mathrm{x} \pm \mathrm{SD}$ (mean \pm standard deviation). The difference between the values in the groups was determined using the Tukey test. The difference was considered significant at $\mathrm{P}<0.05$ (taking into account the Bonferroni correction).

\section{Results}

Feeding laying hens with supplements of lycopene at doses of 20, 40 and $60 \mathrm{mg} / \mathrm{kg}$ or astaxanthin at doses of 10,20 and $30 \mathrm{mg} / \mathrm{kg}$ of feed did not affect the indicators that characterize the quality of eggs: egg weight, albumen height, Haugh unit, strength and shell thickness (Tables 2-4).

\section{Table 2}

The effect of lycopene at a dose of $20 \mathrm{mg} / \mathrm{kg}$ and astaxanthin at a dose of $10 \mathrm{mg} / \mathrm{kg}$ of feed on the quality and carotenoid composition of chicken eggs $(\mathrm{x} \pm \mathrm{SD}, \mathrm{n}=5)$

\begin{tabular}{lccc}
\hline \multicolumn{1}{c}{ Indicator } & Control & LP20 & AST10 \\
\hline Egg weight, g & $57.22 \pm 0.18^{\mathrm{a}}$ & $56.32 \pm 0.13^{\mathrm{a}}$ & $56.84 \pm 0.06^{\mathrm{a}}$ \\
Albumen height, mm & $7.34 \pm 0.55^{\mathrm{a}}$ & $8.08 \pm 0.41^{\mathrm{a}}$ & $7.48 \pm 0.34^{\mathrm{a}}$ \\
Yolk colour, points & $6.10 \pm 0.11^{\mathrm{a}}$ & $7.20 \pm 0.68^{\mathrm{a}}$ & $12.80 \pm 0.22^{\mathrm{b}}$ \\
Haugh unit & $86.18 \pm 3.34^{\mathrm{a}}$ & $90.62 \pm 2.12^{\mathrm{a}}$ & $87.22 \pm 1.95^{\mathrm{a}}$ \\
Eggshell strength, $\mathrm{kgf}$ & $4.33 \pm 0.19^{\mathrm{a}}$ & $4.96 \pm 0.31^{\mathrm{a}}$ & $4.71 \pm 0.06^{\mathrm{a}}$ \\
Shell thickness, mm & $0.38 \pm 0.01^{\mathrm{a}}$ & $0.39 \pm 0.01^{\mathrm{a}}$ & $0.38 \pm 0.01^{\mathrm{a}}$ \\
\hline \multicolumn{4}{c}{ Yolk } \\
\hline Astaxanthin, $\mu \mathrm{g} / \mathrm{kg}$ & $\mathrm{ND}$ & $\mathrm{ND}$ & $354.7 \pm 57.0$ \\
Lycopene, $\mu \mathrm{g} / \mathrm{kg}$ & $\mathrm{ND}$ & $113.0 \pm 38.9$ & $\mathrm{ND}$ \\
$\beta$-carotene, $\mu \mathrm{g} / \mathrm{kg}$ & $18.3 \pm 3.0^{\mathrm{a}}$ & $35.3 \pm 17.6^{\mathrm{ab}}$ & $83.8 \pm 20.0^{\mathrm{b}}$ \\
Unidentified carotenoids in & $13.2 \pm 0.9^{\mathrm{a}}$ & $17.8 \pm 1.3^{\mathrm{b}}$ & $22.6 \pm 2.7^{\mathrm{b}}$ \\
terms of $\beta$-carotene, $\mathrm{mg} / \mathrm{kg}$ & $13.3 \pm 0.9^{\mathrm{a}}$ & $18.0 \pm 1.3^{\mathrm{b}}$ & $23.3 \pm 2.7^{\mathrm{b}}$ \\
\hline Total carotenoids, $\mathrm{mg} / \mathrm{kg}$ & &
\end{tabular}

Note: ND - not detected; different uppercase letters ${ }^{a, b, c}$ indicate values that probably differed in one row of the table $(\mathrm{P}<0.05)$ by comparison using Tukey test with Bonferroni correction.

The addition of lycopene to the diet of chickens at a dose of $20 \mathrm{mg} / \mathrm{kg}$ of feed contributed to its deposition in the yolks, although it did not change the intensity of their colour compared to the control (Fig. 1a, b). Astaxanthin at a dose of $10 \mathrm{mg} / \mathrm{kg}$ of feed also accumulated in the yolks of chicken eggs and increased the intensity of their colour by 6.7 points compared to the control $(\mathrm{P}<0.05$, Fig. 1a, c) and 5.6 points compared to poultry LP20 $(\mathrm{P}<0.05$, Table 2$)$. Astaxanthin dietary supplement increased $(\mathrm{P}<$ $0.05) \beta$-carotene deposition in chicken egg yolks compared to controls. Both LP20 and AST10 diets increased the content of unidentified carotenoids $(\mathrm{P}<0.05)$ and the total content of carotenoids $(\mathrm{P}<0.05)$ in chicken egg yolks compared to the control.

\section{Table 3}

Effect of lycopene at a dose of $40 \mathrm{mg} / \mathrm{kg}$ and astaxanthin at a dose of $20 \mathrm{mg} / \mathrm{kg}$ of feed on the quality and carotenoid composition of chicken eggs $(x \pm S D, n=5)$

\begin{tabular}{lccc}
\hline \multicolumn{1}{c}{ Indicator } & Control & LP40 & \multicolumn{1}{c}{ AST20 } \\
\hline Egg weight, g & $59.74 \pm 0.49^{\mathrm{a}}$ & $58.78 \pm 0.52^{\mathrm{a}}$ & $58.50 \pm 0.66^{\mathrm{a}}$ \\
Albumen height, mm & $9.42 \pm 0.48^{\mathrm{a}}$ & $9.60 \pm 0.26^{\mathrm{a}}$ & $9.04 \pm 0.62^{\mathrm{a}}$ \\
Yolk colour, points & $5.60 \pm 0.27^{\mathrm{a}}$ & $7.40 \pm 0.27^{\mathrm{b}}$ & $14.80 \pm 0.22^{\mathrm{c}}$ \\
Haugh unit & $96.70 \pm 2.12^{\mathrm{a}}$ & $97.82 \pm 1.24^{\mathrm{a}}$ & $94.98 \pm 3.22^{\mathrm{a}}$ \\
Eggshell strength, kgf & $4.47 \pm 0.17^{\mathrm{a}}$ & $4.64 \pm 0.27^{\mathrm{a}}$ & $4.45 \pm 0.34^{\mathrm{a}}$ \\
Shell thickness, $\mathrm{mm}$ & $0.39 \pm 0.02^{\mathrm{a}}$ & $0.39 \pm 0.01^{\mathrm{a}}$ & $0.40 \pm 0.01^{\mathrm{a}}$ \\
\hline \multicolumn{4}{c}{ Yolk } \\
\hline Astaxanthin, $\mu \mathrm{g} / \mathrm{kg}$ & $\mathrm{ND}$ & $\mathrm{ND}$ & $534.7 \pm 24.7$ \\
Lycopene, $\mu \mathrm{g} / \mathrm{kg}$ & $\mathrm{ND}$ & $195.7 \pm 57.8$ & $\mathrm{ND}$ \\
$\beta$-carotene, $\mu \mathrm{g} / \mathrm{kg}$ & $56.3 \pm 9.5^{\mathrm{a}}$ & $121.0 \pm 68.8^{\mathrm{a}}$ & $87.3 \pm 14.1^{\mathrm{a}}$ \\
Unidentified carotenoids in & $11.0 \pm 2.2^{\mathrm{a}}$ & $13.9 \pm 3.6^{\mathrm{a}}$ & $31.0 \pm 4.6^{\mathrm{b}}$ \\
terms of $\beta$-carotene, $\mathrm{mg} / \mathrm{kg}$ & $11.2 \pm 2.2^{\mathrm{a}}$ & $14.3 \pm 3.8^{\mathrm{a}}$ & $31.6 \pm 4.6^{\mathrm{b}}$ \\
Total carotenoids, $\mathrm{mg} / \mathrm{kg}$ & & & \\
\hline
\end{tabular}

Note: see Table 2 .

The use of the LP40 diet increased $(\mathrm{P}<0.05)$ the content of lycopene in chicken egg yolks and the intensity of their colour by 1.8 points $(\mathrm{P}<$ 0.05) compared with the control (Table 3, Fig. 1a, d). The AST20 diet increased the deposition of astaxanthin in chicken egg yolks and improved the intensity of their colour by 9.2 points $(\mathrm{P}<0.05)$ compared with the control (Fig. 1a, e) and by 7.4 points $(\mathrm{P}<0.05)$ compared with the LP40 diet. Lycopene supplementation at a dose of $40 \mathrm{mg} / \mathrm{kg}$ of feed did not affect, and astaxanthin supplement at a dose of $20 \mathrm{mg} / \mathrm{kg}$ of feed increased the content of unidentified carotenoids $(\mathrm{P}<0.05)$ and the total content of carotenoids $(\mathrm{P}<0.05)$ in chicken egg yolks compared to control (Table 3$)$. 
Table 4

The effect of lycopene at a dose of $60 \mathrm{mg} / \mathrm{kg}$ and astaxanthin at a dose of $30 \mathrm{mg} / \mathrm{kg}$ of feed on the quality and carotenoid composition of chicken eggs $(x \pm S D, n=5)$

\begin{tabular}{lccc}
\hline \multicolumn{1}{c}{ Indicator } & Control & \multicolumn{1}{c}{ LP60 } & \multicolumn{1}{c}{ AST30 } \\
\hline Egg weight, g & $60.44 \pm 0.83^{\mathrm{a}}$ & $58.00 \pm 2.56^{\mathrm{a}}$ & $59.54 \pm 2.96^{\mathrm{a}}$ \\
Albumen height, $\mathrm{mm}$ & $7.88 \pm 0.23^{\mathrm{a}}$ & $8.70 \pm 0.48^{\mathrm{a}}$ & $8.00 \pm 0.55^{\mathrm{a}}$ \\
Yolk colour, points & $5.60 \pm 0.27^{\mathrm{a}}$ & $8.00 \pm 0.00^{\mathrm{b}}$ & $14.40 \pm 0.45^{\mathrm{c}}$ \\
Haugh unit & $88.72 \pm 1.47^{\mathrm{a}}$ & $93.20 \pm 1.86^{\mathrm{a}}$ & $84.54 \pm 3.92^{\mathrm{a}}$ \\
Eggshell strength, $\mathrm{kgf}$ & $4.80 \pm 0.22^{\mathrm{a}}$ & $4.20 \pm 0.33^{\mathrm{a}}$ & $4.60 \pm 0.25^{\mathrm{a}}$ \\
Shell thickness, $\mathrm{mm}$ & $0.39 \pm 0.01^{\mathrm{a}}$ & $0.36 \pm 0.02^{\mathrm{a}}$ & $0.36 \pm 0.01^{\mathrm{a}}$ \\
\hline \multicolumn{4}{c}{ Yolk } \\
\hline Astaxanthin, $\mu \mathrm{g} / \mathrm{kg}$ & $\mathrm{ND}$ & $\mathrm{ND}$ & $469.0 \pm 80.3$ \\
Lycopene, $\mu \mathrm{g} / \mathrm{kg}$ & $\mathrm{ND}$ & $283.7 \pm 59.8$ & $\mathrm{ND}$ \\
$\beta$-carotene, $\mu \mathrm{g} / \mathrm{kg}$ & $49.0 \pm 3.9^{\mathrm{a}}$ & $77.0 \pm 16.3^{\mathrm{a}}$ & $83.3 \pm 19.9^{\mathrm{a}}$ \\
Unidentified carotenoids in & $15.5 \pm 0.2^{\mathrm{a}}$ & $16.5 \pm 3.0^{\mathrm{ab}}$ & $25.8 \pm 3.2^{\mathrm{b}}$ \\
terms of $\beta$-carotene, $\mathrm{mg} / \mathrm{kg}$ & $15.8 \pm 0.3^{\mathrm{a}}$ & $16.9 \pm 3.1^{\mathrm{ab}}$ & $26.3 \pm 3.3^{\mathrm{b}}$ \\
Total carotenoids, $\mathrm{mg} / \mathrm{kg}$ & & & \\
\hline
\end{tabular}

Note: see Table 2

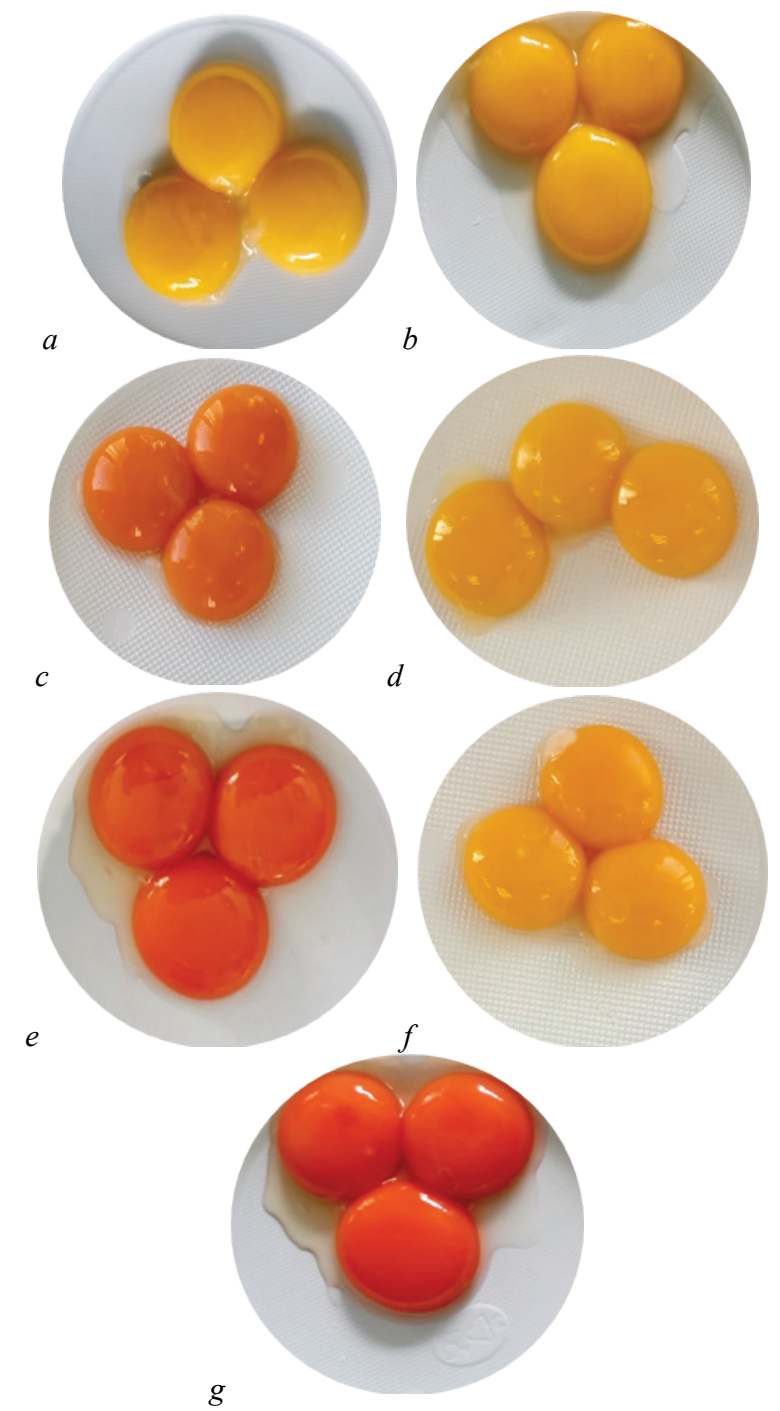

Fig. 1. Colour of egg yolks of chickens of control group $(a)$, $\operatorname{LP} 20(b), \operatorname{AST} 10(c), \operatorname{LP} 40(d), \operatorname{AST} 20(e), \operatorname{LP} 60(f), \operatorname{AST} 30(g)$

Further increase of lycopene content in the diet of laying hens to $60 \mathrm{mg} / \mathrm{kg}$ of feed did not affect the content of $\beta$-carotene, unidentified carotenoids and total carotenoids in egg yolks and increased the deposition of lycopene in egg yolks $(\mathrm{P}<0.05)$ and the intensity of their colour by 2.4 points $\mathrm{P}<0.05$ ) compared with the control (Table 4, Fig. 1a, f). The addition of astaxanthin to the feed of laying hens at a dose of $30 \mathrm{mg} / \mathrm{kg}$ of feed increased the content of astaxanthin $(\mathrm{P}<0.05)$, unidentified carotenoids $(\mathrm{P}<0.05)$, total carotenoids $(\mathrm{P}<0.05)$ and the intensity of yolk colour by 8.8 points compared with the control (Table 4, Fig. 1a, g). However, it should be noted that the intensity of yolk colour and astaxanthin content in the yolks of AST30 hens did not increase compared to the dose of AST20 (Tables 3,4).

\section{Discussion}

Only carotenoids that do not have provitamin activity, including lycopene (Imran et al., 2020) and astaxanthin (Davinelli et al., 2018), are able to accumulate in chicken egg yolks, while $\beta$-carotene is transformed into vitamin $\mathrm{A}$, which although it enters the yolks of chicken eggs, does not affect their colour (Shevchenko et al., 2017a). Feeding laying hens with oil extracts of lycopene and astaxanthin in different doses for 90 days did not affect the indicators characterizing their quality, namely egg weight, albumen height, Haugh unit, strength and shell thickness, which is consistent with the results of studies by An et al. (2019). Previous studies have also shown that carotenoids on the example of $\beta$-carotene have a positive effect on the morphological parameters and chemical composition of quail eggs (Shevchenko et al., 2017b).

The lycopene diet, which was used in our experiment on laying hens, showed that lycopene from the oil extract of tomato products can accumulate in egg yolks. This fact is also confirmed in the studies of Habanabashaka et al. (2014), who showed that the inclusion of tomato flour in amounts of 3-9\% in the diet of laying hens contributed to an increase in lycopene content and the intensity of the colour of chicken egg yolks. Despite the increase in the content of lycopene in the diet of chickens, the intensity of its deposition in the yolks did not increase significantly, which is consistent with the colour of the yolks of eggs of chickens in this group (Fig. 1b, d, f). The results of our studies are consistent with the data obtained by Kang et al. (2003) and Akdemir et al. (2012), which also indicate a certain limitation of the accumulation of lycopene in egg yolks. This may be due to the different ability of lycopene isomers to be absorbed in the digestive tract of birds (Honda et al., 2019). The results of the regression analysis of Olson et al. (2008) confirmed that for optimal inclusion of lycopene in egg yolk it is necessary to feed laying hens lycopene at a dose of $420 \mathrm{mg} / \mathrm{kg}$ of feed, however, saturation of the mechanisms of absorption in the intestine can reduce the intensity of its absorption by $4.5 \%$ at a dose of $65 \mathrm{mg} / \mathrm{kg}$ feed up to $0.6 \%$ for doses up to $650 \mathrm{mg} / \mathrm{kg}$ feed.

The recommended daily dose of lycopene for humans is $10-30 \mathrm{mg}$ (Rao \& Agarwal, 1999). When fed to laying hens on the LP60 diet, one egg weighing $62 \mathrm{~g}$ has a yolk weighing about $18 \mathrm{~g}$, which will contain up to $5 \mu \mathrm{g}$ of lycopene, which is $1 / 2000$ of the recommended dose and does not pose a risk to the health of the consumer. Given the dietary characteristics of edible eggs, enrichment with lycopene will improve their antioxidant properties and biological integrity.

It should also be noted that in our experiment we obtained a significantly lower content of lycopene and $\beta$-carotene in chicken egg yolks using a diet with lycopene oil extract at doses of $20-60 \mathrm{mg} / \mathrm{kg}$ of feed than Omri et al. (2019) for the use of $1 \%$ dried tomato paste and $1 \%$ sweet red pepper. We were unable to obtain a colour scale of egg yolks depending on the dose of lycopene in the diet of chickens $20-60 \mathrm{mg} / \mathrm{kg}$. However (Benamoum et al., 2013), using in the diet of chickens dried tomato peel in doses of $4-13 \%$, the yolk received $12.0-14.6$ against 8.5 points in the control of the colour scale. Such differences in the results of the research are explained by the different basic diet for chickens used by the researchers, as well as the different composition of additives derived from tomato products: oil extract (in our case) and dried powders or paste (in other studies).

The use of astaxanthin oil extract in the diet of chickens in our experiment showed that it increased the deposition of astaxanthin and improved the intensity of yolk colour only at doses of 10 and $20 \mathrm{mg} / \mathrm{kg}$ of feed. Further increase of the dose of astaxanthin supplement to $30 \mathrm{mg} / \mathrm{kg}$ of compound feed was not expedient, as it did not increase the deposition of astaxanthin in the yolks and increase the intensity of their colour (Tables 3, 4). It should be noted that despite the lower content of astaxanthin in the diet of chickens, it stained egg yolks better than lycopene (Fig. 1b-g). This indicates a higher intensity of absorption of astaxanthin compared to lycopene in the digestive system of chickens. A similar conclusion was drawn for the uptake of lycopene and astaxanthin in rats 
(Clark et al., 2000) and intestinal cell culture of Caco-2 (O'Sullivan et al., 2007). This is due to the higher bioavailability of xanthophylls in the organism of animals, to which astaxanthin belongs. The presence of hydroxyl groups in the carotenoid molecule increases their solubility in micellar structures: the lower the hydrophobicity of the carotenoid, the higher its transfer to mixed micelles and the greater its bioavailability (MapelliBrahm, 2017). Highly hydrophobic carotenoids, such as $\beta$-carotene and lycopene, are localized in the inner part of low-density lipoproteins (Kotake-Nara \& Nagao, 2011), which affects the intensity of their absorption in the intestine.

In contrast to lycopene, the addition of astaxanthin oil extract to chicken feed in our experiment in most cases increased the content of $\beta$ carotene, unidentified carotenoids and total carotenoids in egg yolks and allowed them to obtain a colour scale 12.8-14.8 points of the colour spectrum of yolks desired for consumers. As shown in the studies of Spada et al. (2016) among the surveyed 240 consumers, $85 \%$ pay attention to the colour of the yolks when buying eggs, $66 \%$ prefer eggs with yolks enriched with carotenoids. This allows us to consider astaxanthin one of the promising dyes for egg yolks.

Astaxanthin derived from $H$. pluvialis microalgae has been approved as a colorant for use in salmon feed and as a dietary supplement for human consumption at doses up to $12 \mathrm{mg}$ per day for over 20 years and up to $24 \mathrm{mg}$ per day for up to 30 days in Europe, Japan and the United States (Visioli \& Artaria, 2017). If we take into account that a chicken egg weighing $62 \mathrm{~g}$ has a yolk weighing about $18 \mathrm{~g}$, the intake of astaxanthin in the human body for the consumption of one egg of chickens receiving diets AST10, AST20, AST30 (Tables 2-4) will be 6-9 $\mu$ g. This is almost $1 / 1000$ of the above recommended daily human dose and should not pose a health risk. Given the proven positive effect of astaxanthin on the human body (Fakhri et al., 2018), enrichment of egg yolks with this carotenoid will be an important factor in improving their quality and biological integrity (Langi et al., 2018).

\section{Conclusions}

Feeding laying hens with supplements of lycopene oil extracts at doses of 30,40 and $60 \mathrm{mg} / \mathrm{kg}$ and astaxanthin at doses of 10, 20 and $30 \mathrm{mg} / \mathrm{kg}$ of feed for 30 days in increasing concentrations did not affect egg weight, albumen height, Haugh unit, strength and the thickness of the shell. Lycopene oil extract in doses of 20, 40 and $60 \mathrm{mg} / \mathrm{kg}$ increases the content of lycopene and provides the intensity of yolk colour at the level of 7.4 8.0 points. Additions to the diet of laying hens of astaxanthin oil extract in doses of 10, 20 and $30 \mathrm{mg} / \mathrm{kg}$ of feed increase the content of astaxanthin, $\beta$-carotene, the total content of carotenoids in the yolks and the intensity of their colour to 12.8, 14.8 and 14.4 on a 16-point colour scale YolkFanTM. To obtain an attractive colour of chicken egg yolks, it is advisable to use supplements of astaxanthin oil extract in doses of 10 and $20 \mathrm{mg} / \mathrm{kg}$ of feed for 30 days. The obtained research results can be the basis for the development of technology for the production of functional table eggs enriched with lycopene or astaxanthin of natural origin with the colour of the yolks, which corresponds to the food preferences of consumers.

\section{References}

Akdemir, F., Orhan, C., Sahin, N., Sahin, K., \& Hayirli, A. (2012). Tomato powder in laying hen diets: Effects on concentrations of yolk carotenoids and lipid peroxidation. British Poultry Science, 53(5), 675-680.

An, B. K., Choo, W. D., Kang, C. W., Lee, J., \& Lee, K. W. (2019). Effects of dietary lycopene or tomato paste on laying performance and serum lipids in laying hens and on malondialdehyde content in egg yolk upon storage. The Journal of Poultry Science, 56(1), 52-57.

Arain, M., Mei, Z., Hassan, F., Saeed, M., Alagawany, M., Shar, A., \& Rajput, I. (2018). Lycopene: A natural antioxidant for prevention of heat-induced oxidative stress in poultry. World's Poultry Science Journal, 74(1), 89-100.

Bacanli, M., Başaran, N., \& Başaran, A. A. (2017). Lycopene: Is it beneficial to human health as an antioxidant? Turkish Journal of Pharmaceutical Sciences, 14(3), 311-318.

Benamoum, A., Laird, R., \& Zidani, S. (2013). Enriching egg yolk with carotenoids and phenols. International Joumal of Nutrition and Food Engineering, 7(7), $489-493$.
Boyacioglu, M., Kum, C., Sekkin, S., Yalinkilinc, H. S., Avci, H., Epikmen, E. T., \& Karademir, U. (2016). The effects of lycopene on DNA damage and oxidative stress on indomethacin-induced gastric ulcer in rats. Clinical Nutrition, 35(2), $428-435$.

Clark, R. M., Yao, L., She, L., \& Furr, H. C. A. (2000). Comparison of lycopene and astaxanthin absorption from corn oil and olive oil emulsions. Lipids, 35, 803-806.

Danchuk, V., Trach, V., Midyk, S., Danchuk, O., Ushkalov, V., \& Kepple, O. (2019). The fatty acids content in the liver of japanese quails after the chemical treatment of hatching eggs. Foodscience and Technology, 13(2), 58-64.

Davinelli, S., Nielsen, M. E., \& Scapagnini, G. (2018). Astaxanthin in skin health, repair, and disease: A comprehensive review. Nutrients, 10(4), 522.

Dose, J., Matsugo, S., Yokokawa, H., Koshida, Y., Okazaki, S., Seidel, U., Eggersdorfer, M., Rimbach, G., \& Esatbeyoglu, T. (2016). Free radical scavenging and cellular antioxidant properties of astaxanthin. International Journal of Molecular Sciences, 17(1), 103.

Fakhri, S., Abbaszadeh, F., Dargahi, L., \& Jorjani, M. (2018). Astaxanthin: A mechanistic review on its biological activities and health benefits. Pharmacological Research, 136, 1-20.

Farruggia, C., Kim, M. B., Bae, M., Lee, Y., Pham, T. X., Yang, Y., Han, M. J., Park, Y. K., \& Lee, J. Y. (2018). Astaxanthin exerts anti-inflammatory and antioxidant effects in macrophages in NRF2-dependent and independent manners. The Journal of Nutritional Biochemistry, 62, 202-209.

Habanabashaka, M., Sengabo, M., \& Oladunjoye, I. (2014). Effect of tomato waste meal on lay performance, egg quality, lipid profile and carotene content of eggs in laying hens. Iranian Journal of Applied Animal Science, 4(3), 555-559.

Heng, N., Gao, S., Guo, Y., Chen, Y., Wang, L., Sheng, X., Wang, X., Xing, K., Xiao, L., Ni, H., \& Qi, X. (2020). Effects of supplementing natural astaxanthin from Haematococcus pluvialis to laying hens on egg quality during storage at $4{ }^{\circ} \mathrm{C}$ and $25^{\circ} \mathrm{C}$. Poultry Science, 99(12), 6877-6883.

Honda, M., Ishikawa, H., \& Hayashi, Y. (2019). Alterations in lycopene concentration and Z-isomer content in egg yolk of hens fed all-E-isomer-rich and Z-isomer-rich lycopene. Animal Science Journal, 90(9), 1261-1269.

Honda, M., Kawashima, Y., Hirasawa, K., Uemura, T., Jinkun, S., \& Hayashi, Y. (2020). Possibility of using astaxanthin-rich dried cell powder from Paracoccus carotinifaciens to improve egg yolk pigmentation of laying hens. Symmetry, $12,923$.

Imran, M., Ghorat, F., Ul-Haq, I., Ur-Rehman, H., Aslam, F., Heydari, M., Shariati, M. A., Okuskhanova, E., Yessimbekov, Z., Thiruvengadam, M., Hashempur, M. H., \& Rebezov, M. (2020). Lycopene as a natural antioxidant used to prevent human health disorders. Antioxidants, 9, 706.

Kang, D., Kim, S., Cho, C., Yim, Y., \& Kim, H. (2003). Use of lycopene, an antioxidant carotinoid, in laying hens for egg yolk pigmentation. Asian-Australasian Journal of Animal Sciences, 16(12), 1799-1803.

Kotake-Nara, E., \& Nagao, A. (2011). Absorption and metabolism of xanthophylls. Marine Drugs, 9(6), 1024-1037.

Langi, P., Kiokias, S., Varzakas, T., \& Proestos, C. (2018). Carotenoids: From plants to food and feed industries. In: Microbial carotenoids. New York, Humana Press. Pp. 57-71.

Li, F., Huang, S., Lu, X., Wang, J., Lin, M., An, Y., Wu, S., \& Cai, M. (2018). Effects of dietary supplementation with algal astaxanthin on growth, pigmentation, and antioxidant capacity of the blood parrot (Cichlasoma citrinellum $\times$ Cichlasoma synspilum). Journal of Oceanology and Limnology, 36, 1851-1859.

Magnuson, A. D., Sun, T., Yin, R., Liu, G., Tolba, S., Shinde, S., \& Lei, X. G. (2018). Supplemental microalgal astaxanthin produced coordinated changes in intrinsic antioxidant systems of layer hens exposed to heat stress. Algal Research, 33, 84-90.

Mapelli-Brahm, P., Corte-Real, J., Melendez-Martinez, A. J., \& Bohn, T. (2017). Bioaccessibility of phytoene and phytofluene is superior to other carotenoids from selected fruit and vegetable juices. Food Chemistry, 229, 304-311.

Nabi, F., Arain, M. A., Rajput, N., Alagawany, M., Soomro, J., Umer, M., Soomro, F., Wang, Z., Ye, R., \& Liu, J. (2020). Health benefits of carotenoids and potential application in poultry industry: A review. Journal of Animal Physiology and Animal Nutrition, 104, 1809-1818.

Nimalaratne, C., \& Wu, J. (2015). Hen egg as an antioxidant food commodity: A review. Nutrients, 7(10), 8274-8293.

Olson, J. B., Ward, N. E., \& Koutsos, E. A. (2008). Lycopene incorporation into egg yolk and effects on laying hen immune function. Poultry Science, 87(12), 2573-2580.

Omri, B., Alloui, N., Durazzo, A., Lucarini, M., Aiello, A., Romano, R., Santini, A., \& Abdouli, H. (2019). Egg yolk antioxidants profiles: effect of diet supplementation with linseeds and tomato-red pepper mixture before and after storage. Foods, 8(8), 320.

Rao, A. V., \& Agarwal, S. (1999). Role of lycopene as antioxidant carotenoid in the prevention of chronic diseases: A review. Nutrition Research, 19, 305-323.

Shevchenko, L. V., Yaremchuk, O. S., Gusak, S. V., Myhalska, V. M., Poliakovskiy, V. M. (2017a). Effect of glycine microelements and $\beta$-carotene on content of 
microelements and vitamin A in quail eggs. Ukrainian Journal of Ecology, 7(2), 19-23.

Shevchenko, L. V., Yaremchuk, O. S., Gusak, S. V., Myhalska, V. M., Poliakovskiy, V. M. (2017b). Effect of chelating form of microelements and $\beta$-carotene on morphological and chemical composition of quail eggs. Ukrainian Journal of Ecology, 7(2), 5-8
Spada, F. P., Selani, M. M., Coelho, A. A. D., Savino, V. J. M., Rodella, A. A., Souza, M. C., Fischer, F. S., Lemes, D. E. A., \& Canniattige-Brazaid, S. (2016). Influence of natural and synthetic carotenoids on the color of egg yolk. Scientia Agricola, 73(3), 234-242.

Visioli, F., \& Artaria, C. (2017). Astaxanthin in cardiovascular health and disease: Mechanisms of action, therapeutic merits, and knowledge gaps. Food and Function, 8(1), 39-63. 